\title{
REVIEW : APLIKASI TEKNOLOGI NANOPARTIKEL DAN BIOSENSOR DALAM DIAGNOSIS KANKER
}

\section{REVIEW: APPLICATION OF NANOPARTICLE AND BIOSENSOR TECHNOLOGY IN CANCER DIAGNOSIS}

\author{
Atmedi Surendra ${ }^{1}$, Tina Rostinawati ${ }^{2}$ \\ ${ }^{1}$ Magister Fakultas Farmasi, Departemen Biologi Farmasi, Universitas Padjadjaran \\ Jl. Raya Bandung Sumedang KM.21 Jatinangor 45363 \\ ${ }^{2}$ Departemen Biologi Farmasi, Fakultas Farmasi, Universitas Padjadjaran \\ Jl. Raya Bandung Sumedang KM.21 Jatinangor 45363
}

Submitted : 1 Juli 2019 Reviewed : 24 Juli 2019 Accepted: 12 September 2019

\begin{abstract}
ABSTRAK
Penderita kanker global diperkirakan telah mengalami peningkatan setiap tahunnya. Seiring dengan banyaknya kemajuan dalam pengobatan kanker, pengembangan menggunakan pendekatan baru untuk diagnosis kanker yang akurat dan untuk terapi yang ditargetkan berdasarkan penanda spesifik kanker. Nanomedicines bisa menjadi kandidat ideal untuk mencapai tujuan ini. Berbagai nanopartikel dikembangkan untuk pengiriman yang ditargetkan agen diagnostik / terapeutik ke situs kanker, dimaksudkan untuk menghasilkan efektivitas yang lebih besar dan efek samping yang lebih kecil. Biosensor perlu dikembangkan sebagai perangkat bioanalitik yang terkait dengan atau terintegrasi dengan transduser fisikokimia untuk analisis biomarker. Konsep penggunaan nanopartikel dalam pengembangan biosensor untuk diagnosis biomarker akan membuat perangkat ini semakin sensitif. Metode diagnostik yang sederhana dan sensitif yang dapat mendeteksi banyak biomarker kanker akan membantu dalam diagnosis dini dan meningkatkan tingkat kelangsungan hidup pasien kanker.
\end{abstract}

Kata kunci : Biosensor, biomarker, kanker, nanomedicines, nanopartikel

\begin{abstract}
Global cancer patients are estimated to increase every year. Along with the many advances in cancer treatment, the development of using a new approach to cancer diagnosis and for targeted therapies based on cancer-specific markers. Nanomedicines can be ideal candidates for achieving this goal. Various nanoparticles developed for delivery targeted by diagnostic / therapeutic agents to cancer sites, are intended to produce greater effectiveness and smaller side effects. Biosensors need to be developed as bioanalytic devices that associated with or integrated with physicochemical transducers for biomarker analysis. The concept of using nanoparticles in the development of biosensors for biomarker diagnosis will make this device more sensitive. Simple and sensitive diagnostic methods will help in early diagnosis and increase the survival rate of cancer patients.
\end{abstract}

Keywords: Biosensors, biomarkers, cancer, nanomedicines, nanoparticles 


\section{Penulis korespondensi:}

Atmedi Surendra

Magister Fakultas Farmasi, Departemen Biologi Farmasi, Universitas Padjadjaran

Jl. Raya Bandung Sumedang KM.21 Jatinangor 45363

Email: : atmedisurendra@yahoo.com/082149545712

\section{PENDAHULUAN}

Kanker terus menjadi penyakit dengan tingkat kejadian yang tinggi di seluruh dunia. Kanker prostat, paru-paru, payudara, dan usus berada di puncak daftar penyebab kematian pada pasien kanker. Diagnosis dini kanker merupakan faktor penting dalam kelangsungan hidup pasien, dan dapat menentukan keberhasilan dari penanganan penyakit ini. Untuk alasan ini, diperlukan metode yang sensitif dan spesifik untuk mendiagnosis kanker sejak dini (Jemal, 2006). Teknik yang telah berkembang dan mulai banyak dipakai adalah immunoassay (contoh: ELISA), untuk mendeteksi adanya biomarker kanker, dan hanya dilakukan di laboratorium rumah sakit tertentu. Namun, dalam banyak kasus, hanya satu biomarker yang digunakan sebagai indikator penyakit. Immunoassay bersifat sensitif dan selektif, tetapi bisa memakan waktu dan biayanya cukup mahal. Selain itu, beberapa tes ELISA tidak cukup sensitif untuk mendeteksi konsentrasi biomarker pada tingkat rendah, yang ada pada tahap awal penyakit (Tothill, 2009).

Biosensor immunoassay berbasis agregasi pertama kali diperkenalkan pada tahun 1956. Molekul antibodi diimobilisasi ke mikropartikel lateks, digunakan untuk mengikat antigen. Setelah pengikatan antigen, partikel yang dilapisi antibodi berkumpul untuk menghasilkan hasil visual atau terukur (Liu, 2009). Teknologi peggunaan biosensor menawarkan beberapa keuntungan seperti persiapan sampel sederhana, dapat meningkatkan stabilitas uji, serta pengurangan agregasi spesifik dan hasil uji positif palsu. Namun, kelemahan utama dari pendekatan ini adalah sensitivitasnya yang rendah (Du et al., 2008). Sensitivitas biosensor immunoassay dapat ditingkatkan dengan memaksimalkan orientasi fungsional dari situs pengikatan antibodi, meminimalkan ukuran molekul pengikat antigen, dan dapat dioptimalkan dengan adanya konjugasi. Unsur-unsur pengenalan biologis (misalnya: Antibodi), dapat dikonjugasikan dengan material nano untuk mendapatkan sensitivitas yang lebih baik. Kompleksitas dan keanekaragaman dari senyawa biologis membuat sintesis nanopartikel - biomolekul menjadi tantangan besar yang perlu ditelusuri lebih lanjut (Christof, 2001; Backmann et al. 2005; Shen et al., 2005).

Nanoteknologi memainkan peran penting dalam terapi dan diagnosis kanker, dan memberikan solusi untuk masalah yang terjadi dalam metode konvensional. Hal ini menimbulkan perubahan paradigma untuk mempelajari serta berinteraksi dengan sel-sel normal dan kanker secara real time, pada skala molekuler dan seluler selama tahap awal proses kanker. Teknologi ini memberikan peluang untuk membuat kemajuan signifikan dalam diagnosis, dan terapi kanker untuk penargetan spesifik jaringan. Potensi nanomedicines dalam pengembangan obat antikanker tidak terbatas, dengan banyaknya penerapan aplikasi baru lainnya (Brigger, 2002; Allen, 2004; Brannon, 2004).

\section{METODE PENELITIAN}

Sumber data dan strategi pencarian sebagai bahan review jurnal dikumpulkan dengan melakukan teknik pengumpulan data studi literatur yang telah dipublikasikan dalam artikel, jurnal penelitian dan juga textbook. Pencarian dilakukan menggunakan mesin pencarian artikel dan jurnal penelitian seperti google, Elsevier, Pubmed, NCBI dan lain-lain. 


\section{HASIL DAN PEMBAHASAN}

\section{Nanopartikel}

Nanopartikel adalah partikel koloid yang memiliki ukuran 10 hingga $1000 \mathrm{~nm}$. Nanopartikel dan mikropartikel diformulasikan menggunakan polimer sebagai sistem pengiriman gen non viral, karena memiliki karakteristik pelepasan berkelanjutan, biokompatibilitas, biodegradabilitas, dan kemampuan untuk melindungi DNA dari degradasi dalam endolisosom (Brigger, 2002; Panyam, 2003). Selain itu, teknologi nanopartikel sebagai nanomedicine dapat digunakan sebagai pemantauan, perbaikan, konstruksi, dan pengendalian sistem biologis manusia di tingkat molekuler, menggunakan nanodevices dan struktur nano yang direkayasa. Hal ini dapat dianggap sebagai implementasi nanoteknologi di bidang ilmu kesehatan dan diagnostik (Jain, 2003; Emerich, 2005; Moghimi, 2005).

Teknologi nanopartikel diharapkan memainkan peran penting dalam menciptakan sistem penghantaran obat baru secara efisien, yang dapat mengatasi masalah yang terkait dengan pengobatan kanker konvensional. Aplikasi teknologi nanopartikel untuk penghantaran obat secara luas diharapkan dapat menciptakan terapi, dan diagnosis baru serta mampu mengembangkan industri farmasi dan bioteknologi (Emerich, 2003; Sahoo, 2007; Farokhzad, 2008). Pendekatan aplikasi teknologi nanopartikel pada kanker, yaitu mengkonjugasikan nanocarrier yang mengandung komponen kemoterapi atau komponen diagnostik dengan molekul yang berikatan dengan antigen, yang diekspresikan secara berlebihan atau reseptor pada sel target. Nanocarrier dapat menawarkan banyak keunggulan yaitu dapat melindungi obat dari degradasi prematur, mencegah obat berinteraksi secara prematur dengan lingkungan biologis, meningkatkan penyerapan obat ke dalam jaringan yang dipilih, mengontrol profil distribusi jaringan farmakokinetik dan jaringan obat, meningkatkan penetrasi intraseluler (Peer et al., 2007). Keluarga nanocarrier termasuk konjugat polimer, nanopartikel polimer, pembawa berbasis lipid seperti liposom dan misel, dendrimer, nanotube karbon, dan nanopartikel emas (LaVan, 2003; Ferrari, 2005; Duncan, 2006).

Obat yang telah dikombinasikan dengan teknologi nanopartikel, selanjutnya dapat dikonjugasikan dengan suatu ligand agar lebih selektif dan efektif dalam penargetan ke sel targetnya.

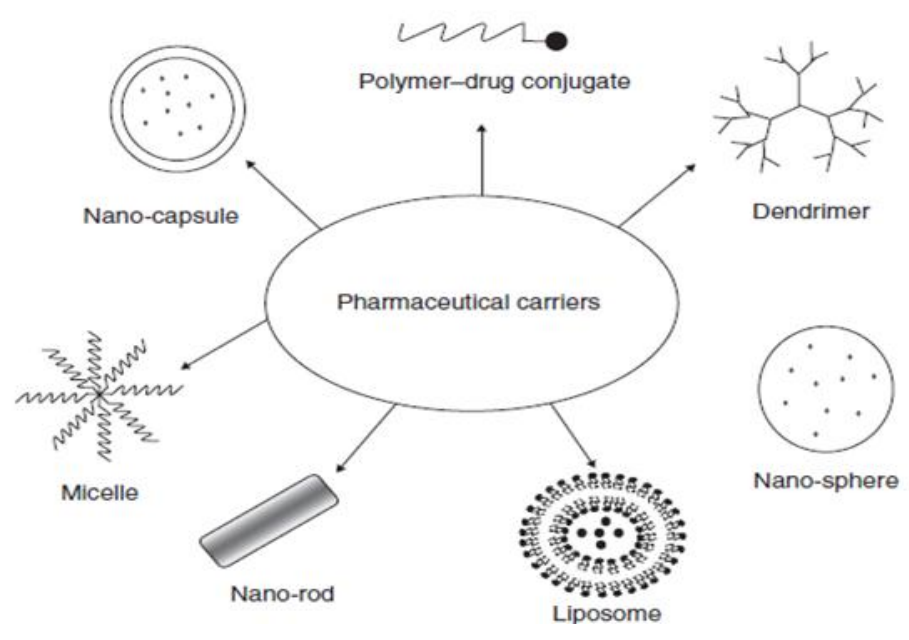

Gambar 1. Nanocarrier (Das et al., 2009) 


\section{Penargetan Berdasarkan Ligand}

Terdapat beberapa obat-obatan yang secara selektif dapat menargetkan sel kanker, dan menghindari akses obat ke daerah non-target menggunakan alat pelacak yang disebut ligand. Ligand juga merupakan molekul yang mengenali dan berikatan dengan antigen target atau reseptor, yang diekspresikan secara berlebihan atau diekspresikan secara selektif oleh sel atau komponen jaringan tertentu. Ligand ideal untuk pengiriman yang ditargetkan adalah yang memiliki afinitas tinggi, memiliki spesifisitas pengikatan pada reseptor permukaan sel, dapatmerangsang internalisasi partikel polimer, kompatibel untuk konjugasi, dan dapat diproduksi dalam jumlah yang cukup (Yukio et al., 1996; Lanza et al., 2002; Sinha et al., 2006; Murphy et al., 2008).

Ligand memiliki dampak signifikan pada kinetika pelepasan obat. Profil pelepasan obat yang terkonjugasi ligand jauh lebih rendah dari yang tidak terkonjugasi. Terlepas dari kekosongan seperti itu, obat yang dikonjugasi lebih efektif daripada yang tidak, karena dapat mencapai situs targetnya dengan lebih efisien (Eniola, 2003; Keegan et al., 2004). Ligand berikatan dengan sel target yang spesifik seperti biomarker kanker yang diekspresikan secara berlebih.

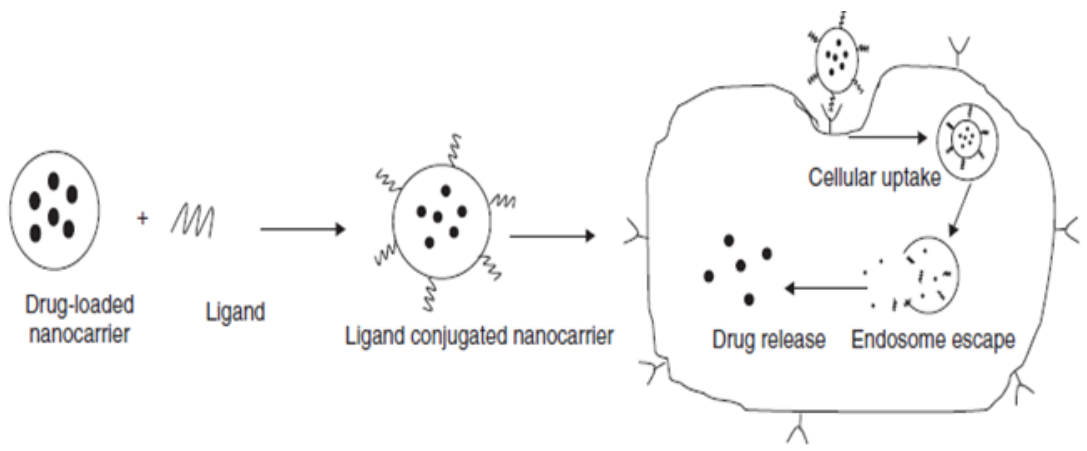

Gambar 2. Penargetan aktif oleh Ligand (Das et al., 2009)

\section{Biomarker Kanker}

Antigen terkait tumor telah digunakan sebagai biomarker untuk diagnosis kanker. Biomarker tersebut terdiri dari molekul seluler yang dapat dideteksi dalam sel-sel tumor, darah, urin, atau cairan tubuh lain yang diekspresikan berlebihan karena onset dan pertumbuhan kanker. Sampai saat ini ada sejumlah biomarker yang telah diidentifikasi dengan berbagai jenis kanker (Gunawardana, 2007). Berbagai entitas pengenalan molekuler telah digunakan untuk deteksi biomarker. Yang paling banyak digunakan adalah molekul antibodi, yang menyediakan spesifisitas dan sensitivitas yang diperlukan untuk tingkat rendah deteksi molekul (Tothill, 2001; Shaikh, 2005; Collett, 2005).

Biomarker dapat digunakan untuk diagnosis dini, pemantauan penyakit dan prognosis serta penanda prediktif. Banyak biomarker yang masih melalui evaluasi untuk meningkatkan spesifisitas dan sensitivitas dalam penggunaan klinisnya (Sanchez, 2004). Protein yang diekspresikan secara berlebihan sebagai hasil dari pertumbuhan sel kanker telah digunakan sebagai biomarker untuk diagnosis kanker. Sebagai contoh, antigen spesifik prostat (PSA), yang bertanggung jawab untuk pencairan cairan mani dan juga hadir dalam serum pasien pria, digunakan sebagai biomarker. Tingkat PSA dapat meningkat secara nyata dalam serum karena kanker prostat. Oleh karena itu, protein ini telah digunakan sebagai biomarker kanker prostat untuk diagnosis dan pemantauan. Namun, meskipun PSA adalah penanda yang sangat sensitif, spesifisitasnya rendah (Phillips et al., 2003; Eble, 2004). Untuk mengenali secara spesifik biomarker kanker, bahan pengenalan yang optimal harus diimplementasikan sebagai reseptor dalam desain biosensor. Ini sangat penting untuk diagnosis medis karena sensitivitas dan spesifisitas akan memainkan peran penting dalam keberhasilan perangkat sensor. 


\begin{tabular}{ll}
\hline Cancer type disease & Biomarker \\
\hline Prostate & PSA, PAP \\
Breast & CA15-3, CA125, CA27.29, CEABRCA1, BRCA2, \\
& MUC-1, CEA, NY-BR-1, ING-1 \\
Leukaemia & Chromosomal abnormalities \\
Testicular & gonadatropin, CAGE-1, ESO-1 \\
& CA125, AFP, hCG, p53, CEA \\
Ovarian & Circulating tumour cells in biological fluids, \\
Any solid tumour & expression of targeted growth factor receptors \\
& CEA, CA19-9, CA24-2, p53 \\
Colon and pancreatic & NY-ESO-1, CEA, CA19-9, SCC, CYFRA21-1, NSE \\
Lung & Tyrosinase, NY-ESO-1 \\
Melanoma & AFP, CEA \\
Liver & CA72-4, CEA, CA19-9 \\
Gastric carcinoma & SCC \\
Esophagus carcinoma & SCC, hCG \\
Trophoblastic & BAT, FDP, NMP22, HA-Hase, BLCA-4, CYFRA 21-1 \\
Bladder &
\end{tabular}

Gambar 3. Contoh biomarker kanker untuk diagnosis dan prognosis (Tothill, 2009)

\section{Biosensor Sebagai Alat Diagnosis}

Biosensor didefinisikan sebagai perangkat bioanalitik yang menggabungkan entitas pengenalan molekul yang terintegrasi dengan transduser fisikokimia. Untuk mengembangkan teknologi biosensor yang tepat, biomarker spesifik perlu diidentifikasi untuk memastikan spesifisitas perangkat. Biosensor menyediakan analisis biomarker dengan beberapa keuntungan antara lain mudah digunakan, murah, cepat, dan kuat serta menawarkan kemampuan pengujian multi-analit untuk diagnosis kanker (Tothill, 2009).

Dalam perkembangan diagnosis kanker, dibutuhkan metode yang dapat efektif untuk mendeteksi dini adanya kanker pada pasien. Aplikasi tersebut dapat dikembangkan lebih lanjut dengan mengkombinasikan metode terbaik yang telah ada, yaitu teknologi nanopartikel dan teknologi biosensor sehingga dapat diperoleh metode yang lebih baik dari sebelumnya.
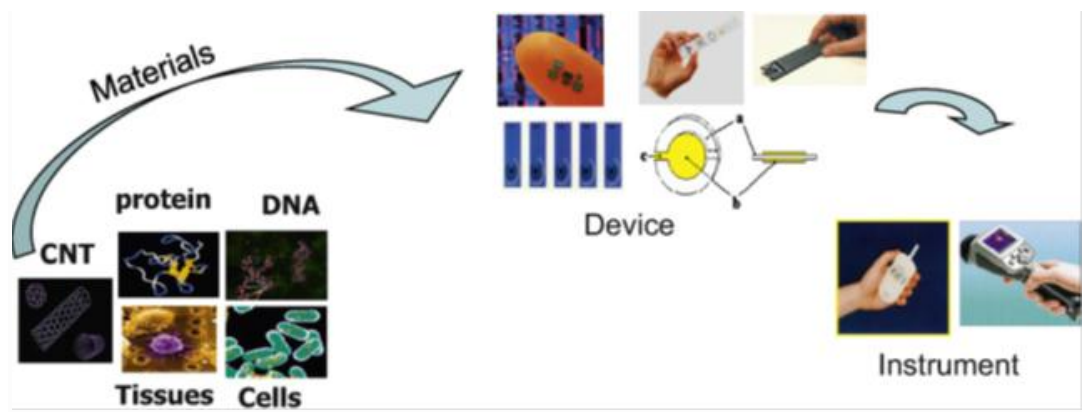

Gambar 4. Konstruksi biosensor (Tothill, 2009)

\section{Aplikasi Kombinasi Nanopartikel Dan Biosensor Pada Diagnosis Kanker}

Pengiriman obat ke jaringan target dapat dicapai terutama dengan dua cara dasar: a) penargetan pasif; dan b) penargetan aktif. Penargetan pasif mengacu pada akumulasi obat atau sistem pembawa obat di lokasi yang diinginkan karena faktor fisikokimia atau farmakologis. Penargetan aktif mengambil keuntungan dari perbedaan antara sel kanker dan sel normal dalam hal reseptor dan ekspresi antigen. Berbagai reseptor permukaan sel dan beberapa antigen diekspresikan secara unik hanya dalam sel kanker. Penargetan aktif biasanya menggunakan konjugasi permukaan nanopartikel dengan bagian penargetan yang disebut ligand, yang memiliki afinitas selektif untuk reseptor permukaan atau antigen pada sel, jaringan atau organ tertentu dalam tubuh (Garnett, 2001; Nishioka, 2001; Gu et al., 2008; Parveen, 2008). 
Aplikasi kombinasi nanopartikel dalam pengembangan biosensor berkisar pada perangkat transduser, ligan pengenalan, label dan sistem nanorunning. Peningkatan penggunaan metode ini disebabkan oleh keunggulan luar biasa yang ditawarkan yaitu melalui miniaturisasi perangkat, peningkatan sinyal, dan penguatan sinyal oleh label nanopartikel sehingga meningkatkan sensitivitas (Jain, 2004; Sun et al., 2005).

Nanopartikel emas dan perak dapat digunakan dalam metode kombinasi dengan biosensor termasuk nanokristal anorganik lainnya yang berbeda (misal: $\mathrm{ZnS}, \mathrm{PbS}$, dan $\mathrm{CdS}$ ) untuk mendeteksi biomarker. Beberapa produk tersedia di pasaran seperti Oxanica (UK) Quantum dots dan MultiPlxBeads ${ }^{\mathrm{TM}}$ dari Crystalplex Corp., USA. Oxanica juga memasarkan produk Nanoplex ${ }^{\mathrm{TM}}$ yang didasarkan pada perangkat aliran lateral dan menggunakan nanopartikel untuk deteksi biomarker. Nanopartikel juga dapat dieksploitasi dalam sensor berbasis konduktivitas di mana mereka dapat menginduksi perubahan sinyal pada lampiran konjugat nanopartikel-antibodi, ditandai dengan antigen yang ditangkap pada permukaan sensor (Tothill, 2009). Choi et al. (2008) melaporkan penggunaan nanopartikel emas untuk mendeteksi antigen spesifik prostat menggunakan SPR (surface plasmons resonance).

\section{KESIMPULAN}

Mendiagnosis kanker lebih awal merupakan hal terpenting untuk keberhasilan perawatan dan pemulihan pasien yang menderita penyakit ini. Oleh karena itu diperlukan metode diagnostik yang sederhana dan sensitif yang dapat mendeteksi banyak biomarker kanker yang ada pada konsentrasi rendah dalam cairan biologis. Metode biosensor dapat memenuhi persyaratan ini. Namun, perangkat biosensor bisa dikembangkan lebih lanjut lagi agar sensitivitasnya meningkat. Konsep kombinasi nanopartikel dalam pengembangan biosensor untuk diagnosis biomarker akan membuat perangkat ini sangat sensitif dan lebih berlaku untuk diagnosis dini tempat perawatan. Diagnosis dini akan membantu dalam meningkatkan tingkat kelangsungan hidup pasien penderita kanker. Pengembangan biosensor yang sukses dalam diagnosis kanker akan membutuhkan dana yang sesuai untuk melanjutkan teknologi dari penelitian ke realisasi produk komersial.

\section{DAFTAR PUSTAKA}

Allen TM, Cullis PR. 2004. Drug delivery systems: entering the mainstream. Science; 303:1818-22.

Backmann N, Zahnd C, Huber F, Bietsch A, Pluckthun A, Lang HP, Guntherodt HJ, Hegner M, Gerber C. 2005. A label-free immunosensor array using single-chain antibody fragments. Proc Nat Aca Sci.; 102 (41):14587-14592.

Brannon-Peppas L, Blanchette JO. 2004. Nanoparticle and targeted systems for cancer therapy. Adv Drug Deliv Rev;56:1649-59.

Brigger I, Dubernet C, Couvreur P. 2002. Nanoparticles in cancer therapy and diagnosis. $A d v$ Drug Deliv Rev;54:631-51.

Choi J-W, Kang D-Y, Jang Y-H, Kim H-H, Min J, Oh B-K. 2008. Ultra-sensitive surface plasmon resonance based immunosensor for prostate specific antigen using gold nanoparticale antibody complex. Colloids Surf A: Physicochem Eng Aspects;313314:655-9.

Christof MN. 2001. Nanoparticles, Proteins, and Nucleic Acids: Biotechnology Meets Materials Science. Angew Chem Inter Ed;40(22):4128-4158.

Collett JR, Cho EJ, Lee JF, LevyM, Hood AJ,Wan C, et al. 2005. Functional RNAmicroarrays for high-throughput screening of antiprotein aptamers. Anal Biochem;338:113-23.

Das, M., Mohanty, C., \& Sahoo, S. K. 2009. Ligand-based targeted therapy for cancer tissue. Expert Opinion on Drug Delivery, 6(3), 285-304. 
Du BA, Li ZP, Cheng YQ. 2008. Homogeneous immunoassay based on aggregation of antibody-functionalized gold nanoparticles coupled with light scattering detection. Talanta;75(4):959-964. [PubMed:18585169]

Duncan, R. 2006. Polymer conjugates as anticancer nanomedicines. Nat. Rev. Cancer 6, 688-701.

Eble JN, Sauter G, Epstein JI, Sesterhenn IA. 2004. World Health Organization classification of tumours. pathology and genetics of tumours of the urinary system and male genital organs. Lyon: IARC Press.

Emerich DF, Thanos CG. 2003. Nanotechnology and medicine. Expert Opin Biol Ther.3:6 55-63.

Emerich D. 2005. Nanomedicine - prospective therapeutic and diagnostic applications. Expert Opin Biol Ther:;(5):1-5.

Eniola AO, Hammer DA. 2003. Artificial polymeric cells for targeted drug delivery. $J$ Control Release;87:15-22.

Farokhzad OC. 2008. Nanotechnology for drug delivery: the perfect partnership. Expert Opin Drug Deliv;5:927-29.

Ferrari, M. 2005.Cancer nanotechnology: opportunities and challenges. Nat. Rev. Cancer 5, $161-171$.

Garnett MC. 2001. Targeted drug conjugates: principles and progress. Adv Drug Deliv Rev;53:171-216.

Gu F, Zhang L, Teply B, et al. 2008. Precise engineering of targeted nanoparticles by using self-assembled biointegrated block copolymers. PNAS;105:2586-91.

Gunawardana CG, Diamandis EP. 2007. High throughput proteomic strategies for identifying tumour-associated antigens. Cancer Lett;249:110-9.

Jain KK. 2003. Nanodiagnostics: application of nanotechnology in molecular diagnostics. Expert Rev Mol Diagn;3:153 - 61.

Jain KK. 2004. Applications of biochips: from diagnostics to personalized medicine. Curr Opin Drug Discov Dev;7:285-9.

Jemal A, Siegel R, Ward E, Murray T, Xu J, Smigal C, et al. 2006. Cancer statistics. $C A$ Cancer J Clin;56:106-30.

Keegan M, Falcone J, Leung T, et al. 2004. Biodegradable microspheres with enhanced capacity for covalently bound surface ligands. Macromol;37:9779-84.

Lanza GM, Yu X, Winter PM, et al. 2002. Targeted antiproliferative drug delivery to vascular smooth muscle cells with a magnetic resonance imaging nanoparticle contrast agent: implications for rational therapy of restenosis. Circulation;106:28427.

LaVan DA, McGuire T, Langer R. 2003. Small-scale systems for in vivo drug delivery. Nat Biotechnol;21:1184-91.

Liu, Y., Liu, Y., Mernaugh, R. L., \& Zeng, X. 2009. Single chain fragment variable recombinant antibody functionalized gold nanoparticles for a highly sensitive colorimetric immunoassay. Biosensors and Bioelectronics, 24(9), 2853-2857.

Moghimi SM, Hunter AC, Murray JC. 2005. Nanomedicine: current status and future prospects. Faseb J;19:311-30.

Murphy EA, Majeti BK, Barnes LA, et al. 2008. Nanoparticle-mediated drug delivery to tumor vasculature suppresses metastasis. Proc Natl Acad Sci USA;105:9343-8.

Nishioka Y, Yoshino H. 2001. Lymphatic targeting with nanoparticulate system. Adv Drug Deliv Rev;47:55-64.

Panyam J, Labhasetwar V. 2003. Biodegradable nanoparticles for drug and gene delivery to cells and tissue. Adv Drug Deliv Rev;55: 329- 47.

Parveen S, Sahoo SK. 2008. Polymeric nanoparticles for cancer therapy. J Drug Target; $16: 108-23$.

Peer, D., Zhu, P., Carman, C. V., Lieberman, J. \& Shimaoka, M. 2007. Selective gene silencing in activated leukocytes by targeting siRNAs to the integrin lymphocyte function-associated antigen-1. Proc. Natl Acad. Sci. USA 104, 4095-4100. 
Phillips M, Cataneo R, Ditkoff B, Fisher P, Greenberg J, Gunawardena R, et al. 2003. Volatile markers of breast cancer in the breath. Breast J;9(3):184-91.

Sahoo SK, Parveen S, Panda JJ. 2007. The present and future of nanotechnology in human health care. Nanomedicine;3:20-31.

Sanchez-Carbayo M. 2004. Recent advances in bladder cancer diagnostics. Clin Biochem;37:562-71.

Shaikh KA, Ryu KS, Goluch ED, Nam JM, Liu J, Thaxton CS, et al. 2005. A modular microfluidic architecture for integrated biochemical analysis. Proc Natl Acad Sci USA;102:9745-50.

Shen Z, Mernaugh RL, Yan H, Yu L, Zhang Y, Zeng X. 2005. Engineered Recombinant Single-Chain Fragment Variable Antibody for Immunosensors. Anal Chem;77(21):6834-6842. [PubMed: 16255580]

Sinha R, Kim GJ, Nie S, et al. 2006. Nanotechnology in cancer therapeutics: bioconjugated nanoparticles for drug delivery. Mol Cancer Ther;5:1909-17.

Sun CP, Liao JC, Zhang YH, Gau V, Mastali M, Babbitt JT, et al. 2005. Rapid, species specific detection of uropathogen $16 \mathrm{~S}$ rDNA and rRNA at ambient temperature by dot-blot hybridization and an electrochemical sensor array. Mol Genet Metab;84:909.

Tothill IE. 2001. Biosensors developments and potential applications in the agricultural diagnosis sector. Comput Electron Agric;30:205-18.

Tothill, I. E. 2009. Biosensors for cancer markers diagnosis. Seminars in Cell \& Developmental Biology, 20(1), 55-62.

Yukio K, Takeshi S, Takashi K, et al. 1996. Kinetic analysis of receptor-mediated endocytosis (RME) of proteins and peptides: use of RME as a drug delivery system. $J$ of Control Release;39:191-200. 